\title{
Swiss extractivism: Switzerland's role in Zambia's copper sector*
}

\author{
GREGOR DOBLER \\ University of Freiburg, Institut für Ethnologie, Werthmannstr. Io, 79085 \\ Freiburg, Germany
}

Email: gregor.dobler@ethno.uni-freiburg.de

and

Rita KeSSELRING

University of Basel, Ethnologisches Seminar, Münsterplatz I9, 405 I Basel, Switzerland

Email: rita.kesselring@unibas.ch

\author{
A B S T R A C T
}

Switzerland is usually not looked upon as a substantial economic actor in Africa. Taking Zambian copper as a case study, we show how important Swiss companies have become in the global commodities trade and the services it depends on. While big Swiss trading firms such as Glencore and Trafigura have generated increasing scholarly and public interest, a multitude of Swiss companies is involved in logistics and transport of Zambian copper. Swiss extractivism, we argue, is a model case for trends in today's global capitalism. We highlight that servicification, a crucial element of African mining regimes today, creates new and more flexible opportunities for international companies to capture value in global production networks. These opportunities partly rely on business-friendly regulation and tax regimes in Northern countries, a fact which makes companies potentially vulnerable to

\footnotetext{
* Research for this article has been funded by SNIS, the Swiss Network for International Studies. We are grateful to all project partners in the Valueworks project. We finished the article as Fung Global Fellow at the Institute for International and Regional Studies (PIIRS), Princeton University (Rita Kesselring), and as Visitor at the Institute for Advanced Study, Princeton (Gregor Dobler); we are very grateful to both institutions for the inspiring writing environment they offered. Two anonymous reviewers have provided very valuable criticism. Most of all, we want to thank our Zambian research partners for their hospitality, their interest in our research and their patience for our curiosity.
} 
reputation risks and offers opportunities to civil society actors criticising their role. New and different Swiss-Zambian connections emerge from civil society networks organising around companies' economic activities.

I N T R O D U C T I O N : EXTRACT IVIS M

This essay is on the economic infrastructure of extractivism and its role in global capitalism. When analysing extractivism - a reliance of countries on the export of raw materials that creates economic and political dependence and redirects profits to other countries (Acosta 2013; Gudynas 2018), social scientists often focus on the sites of extraction: on mines, oil fields or plantations. In African studies, the topic has attracted renewed interest since China's economic growth changed the landscape of global extraction and generated a new wave of large-scale commodity investments (Womin 2013; Ayelazuno 2014; Dobler 2017; Engels \& Dietz 2017; Schubert et al. 2018). Scholars have shown the role played by multinational companies and their managers (Lee 2017) and have analysed the relations between large investors, host communities and governments of resource-rich countries (Kesselring 2018a). Environmental problems have found as much coverage as resettlement programmes, corporate social responsibility measures or labour relations (Kirsch 2014; Welker 2014; Benya 2015; Dolan \& Rajak 2016). These studies have shown commodity extraction's enormous impact on people who live around the mines and oil fields, and have linked this impact to power relations in the global economy.

The political economy of extractivism, however, cannot be understood by concentrating on pits and wells alone. Between their extraction and their use in global industrial production, commodities have to be financed, insured, moved, stored, cleaned, weighed, blended, bought, sold, certified, tracked to mention just a few downstream activities. Service providers such as trading firms, transport and shipping companies, financial institutions, certification and software providers are as important agents of commodity extraction as mining companies. These segments of global production networks figure less prominently in the literature. The ensuing imbalance distorts our image of the ways in which commodity-exporting countries are embedded into the global economy.

Using the relations between Zambia and Switzerland as an example, we show in this article how active international companies are in providing the infrastructure of Southern Africa's mineral extraction, and how they manage to capture a substantial percentage of the value created by it. We argue that in order to understand the consequences of mineral extraction for host countries and ultimately increase local benefits through regulation and effective taxation, we need to pay much more attention to these less spectacular, but no less profitable activities.

We are not the first to argue along these lines. Scholars of global value chains have long been interested in the different ways value is added to goods along their journey (Gereffi 2014), while theorists of global production networks 
highlight the functional role of intermediaries such as financial, logistics and standard-setting agents (Yeung \& Coe 2015: 42, 50). More recently, a new focus on the 'servicification' of global value chains has made clear that manufacturing firms in advanced economies frequently generate a high percentage of their revenue through service provision (Miroudot 2017). Most studies on servicification, however, have focused on industries in Europe, the USA and Asia, and little is known about the extent to which services contribute to value addition in mineral extraction in African countries. We hope that our article draws attention to this gap and increases interest in the less spectacular sides of commodity extraction.

Our case study is restricted in focus: we analyse the role of Swiss companies in Zambia's copper sector. We concentrate on one commodity and one pair of countries, and we only include activities downstream of mining that take place in Southern Africa.

Zambia, currently the world's 8th largest producer of copper, is highly dependent on mining. The extractive sector accounts directly for $10 \%$, indirectly for up to $50 \%$ of its GDP, and for $80 \%$ (2016) of exports. Despite this, mining only contributed $18 \%$ to government revenue in 2015 , the largest part coming from mineral royalties (Zambia EITI 2017).

According to official trade statistics, half of Zambia's copper is exported to Switzerland - that is, bought and sold by Swiss commodity trading firms. This is typical of Switzerland's role in the global economy. The country has developed into a global trade hub; $60 \%$ of the world's metals, $60 \%$ of coffee, $5^{0} \%$ of sugar, $35 \%$ of grains and $35 \%$ of crude oil are today traded via Switzerland (Lannen et al. 2016).

When we started our research, we wanted to better understand the consequences of Switzerland's role as a trade hub for Zambian copper. We soon realised that commodity trade is just one of the ways the Swiss and the Zambian economy are interlinked. In our description and analysis of these links, we do not want to single out Swiss companies as exceptional, and we see the danger that the national focus could downplay global connections of capital. We will show, however, that a focus on Switzerland makes the general dynamics of global capitalism more clearly visible. It is a useful heuristic tool for understanding regional disparities and value capture in global capitalism.

Methodically, the article draws on ethnographic research in border and mining towns in Southern Africa. Gregor Dobler has worked in this context for the last 15 years and has done short-term fieldwork for this article in Chirundu and Lusaka; Rita Kesselring has conducted 18 months of ethnographic fieldwork in Solwezi and Kalumbila, two new mining towns in northwestern Zambia, and, to a lesser degree, in Mufulira and Kitwe, two old Copperbelt towns. We both have conducted interviews with a wide range of industry actors in Zambia and Switzerland, and done extensive desk research for areas in which we found access difficult. ${ }^{1}$

The article's structure is simple. After a short introductory overview, we follow copper's journey through the main stages of mining, trade and transport 
logistics. At each stage, we show the extent and manner of Swiss companies' involvement. A second, shorter part then looks at a different link between the countries emerging from their economic interactions: solidarity movements between civil society groups. We show that for companies who use favourable regulatory environments as a major asset, such critical movements have become a strategic risk and standard-setting agents in themselves. In the conclusion, we bring these strands together to theorise the role of Swiss companies in the global partition of labour.

\section{E X T R A C T I O N}

Our interest not in mining alone but in copper's entire production network is one of the few things we share with Glencore, the best-known Swiss company active in Zambia's copper sector. Glencore started out as a commodity trader, but has by now become an integrated multinational commodity firm. One major step in this direction has been its investment in copper mines in Zambia and the DRC since 200o. Glencore's decision to buy mines in Zambia was anticyclical and, in retrospect, came at the best possible moment for the company.

Zambia has had a long history of commercial copper extraction. Under the British South Africa Company's and later British colonial rule, its copper mines were owned by the Anglo American Corporation and the Roan Selection Trust. In 1969, five years after independence, the Zambian government nationalised the country's copper mines. In 1982, in response to a long depression in copper prices beginning in the mid-197os, the two state-owned mining enterprises were amalgamated to create Zambia Consolidated Copper Mines Limited (ZCCM). ZCCM's main shareholders were the Zambian government with 60.3\% and the Anglo American Corporation with 27.3\%. The consolidation could not stop the sector's decline. In an environment of global liberalisation and deregulation, increasing external debts and lack of revenue forced President Kaunda to give in to pressure by the International Monetary Fund, the World Bank and other lenders to privatise the mines and other state assets (Simutanyi 1996; Craig 2001).

The scope and the pace of the country's privatisation and liberalisation program increased under the Movement for Multi-Party Democracy (MMD) led by Frederick Chiluba (Fraser \& Larmer 2010). In 1996, the Zambian government began unbundling ZCCM into asset packages and selling those to various investors, while maintaining a minority interest in each new company. Due to the global price slump of the 199os, it took until 2000 before all assets were privatised, after years of hard negotiations, low bids and increased debt.

Glencore acquired a majority stake in Mopani copper mines, the largest employer on the Copperbelt - comprising Nkana and Mufulira mines, two concentrators, one smelter, one refinery and two cobalt plants. In 2000, Carlisa Investments Corp, a joint venture between First Quantum Minerals Limited (FQM, see below) and Glencore International AG incorporated in the British 
Virgin Islands, acquired a 90\% share in Mopani. Very soon, FQM diluted its interest in the company, which reduced its shares in the Mopani copper mines from $45.9 \%$ to $16.9 \%$ and increased Glencore's from $44.1 \%$ to $76.3 \%$. The remaining $10 \%$ are still owned by ZCCM (FQM 2002).

As with all ZCCM assets, conditions for the sale of Mopani were codified in a secret bilateral Development Agreement later leaked to the public. The agreement defined a 'stability period' of 15 years during which contractual conditions would remain stable. It exempted Glencore and FQM from covering ZCCM's financial liabilities (including pensions for ZCCM workers) and environmental legacies, and from paying most taxes (Adam \& Simpasa 2010: 67-8). Although the development agreements ceased to be binding following their cancellation in the Mines and Minerals Development Act 2008, many of their provisions remain in place.

Today, Glencore is the fourth largest copper producer by output in Zambia after FQM, Barrick Gold and Vedanta. It also owns Sable Zinc Kabwe Limited, a copper and cobalt processing plant in Kabwe (Glencore 2018: 192), Mutanda mine and $74.4 \%$ of Katanga Mining in neighbouring DRC.

Glencore's Swiss history is well known. The company goes back to Marc Rich \& Co AG, registered in Zug, Switzerland in 1974. Rich, by then on the FBI's 10 most wanted fugitives list for charges of, among others, tax evasion, racketeering and evading US sanctions in trading with Iran, sold his trading business to the company's managers in 1993. (He was later famously pardoned by Bill Clinton on his last day in office, after Rich's wife Denise Rich had donated more than US\$ 1 million to the Democratic Party.) The new company, Glencore, went public in 2011 and merged with Swiss mining giant Xstrata in 2012/13. Today, it is the world's largest commodity trading company. Glencore plc is incorporated in Jersey and domiciled in Baar, Switzerland. Shareholders in Glencore plc include institutional investors, such as Qatar Holding $(8.47 \%)$ and BlackRock Inc. $(5.69 \%)$, but large shares in the company are owned by managers, e.g. CEO Ivan Glasenberg $(8.40 \%)$ and Aristotelis Mistakidis (3.12\%) (Glencore 2018: 106-7). ${ }^{2}$

Since the 2ooos, Glencore was one of the first major commodity traders to extend its reach along the value chain - a strategy now followed by many of the industry's giants, since margins from arbitrage have declined in an age of more readily available pricing information (Bloomberg 2017). Its expansion into mining has generated many discussions - some of them linked to the economic benefits or dangers of vertical integration, others to the business practices or environmental effects of its mines and smelters. Employees of other Zambian mining companies we spoke to see Glencore as driven by a different, non-mining logic (see also Lee 2017: 65), while employees of other Swiss trading companies see Glencore as an opaque and somewhat shady behemoth.

Global copper prices rose six-fold after Glencore's acquisition of Mopani, from US $\$ 1,5$ oo per metric ton in 2000 to over US $\$ 10$,ooo per ton in February 2011. After 2012, the price gradually fell to below US $\$ 5$, ooo in 2016 , only to recover to US\$6,000-7,000 at the moment of writing. Due to 
the privatisation of mining assets and an unfavourable tax regime, little of the ensuing profit remained in the country. The government's multiple attempts to increase revenues from mining have largely failed due to companies' bargaining power (Manley 2017; Saunders \& Caramento 2018: $5^{-9}$ ).

T R A D E

Mining companies based in Zambia do not use copper for production purposes, but sell their product to other companies. Mines rarely sell copper directly to economic actors who need physical copper for production. Instead, copper passes into the hands of specialised traders who sell it on to other traders or consumers. Traders have a double role. On the one hand, they render services to producers and consumers by allocating copper more cost-efficiently than either consumers or producers could do on their own. Traders have access to a large number of producers and consumers and can save on transport costs by matching supply and demand across different regions of the world; they finance transport and storage of commodities, allowing producers and consumers to optimise cash flow and save costs; and they can more efficiently hedge against market risks than smaller actors could, keeping costs for other actors stable and predictable. For these services, they receive a share of the production network's overall profits. This share is, at least in textbook economic theory, smaller than the costs the other actors in the production network would have without the traders - otherwise customers would circumvent them and source their copper directly from the mines. Trading firms thus ideally make the production network more efficient. If their business is centred on the allocation element of trade, trading firms typically make relatively small, but predictable profits on each transaction. Their profits add up from high volumes rather than from high margins.

On the other hand, trading firms engage in speculative trade to increase their own profits. They try to anticipate price developments and bet against the markets. In this side of their business, traders are not the agents of either producers or consumers, but act for the interest of capital owners (and their own bonuses). Traders argue that much speculative trade is in the interest of all market participants, since it contributes to fair pricing and overall price stability. Critics however point out that speculative trade creates high risks and contributes to a concentration of profits in the hands of big capital owners while externalising market risks to less powerful investors.

\section{The Swiss trading hub}

While mining and, to a lesser degree, industrial production is strictly localised, commodities can be bought and sold independently of their physical location. This has allowed Switzerland, a landlocked country without many natural resources, to become one of the most important hubs of global commodity trade (Haller 2019). 
Switzerland has a long history of trade and has often profited from trade with African commodities - from slaves (Fässler 2005) to cocoa and coffee. Partly growing from such earlier roots, Swiss commodity trade has taken off to a surprising degree over the last two decades, surviving the financial crisis unscathed (Beusch et al. 2013). Switzerland generated 3.7\% of its GDP in 2016 from commodity trading - a higher share than banking or tourism (Lannen et al. 2016). In 2017, the five largest Swiss companies by turnover were commodity traders: Glencore, Vitol, Trafigura, Cargill and Mercuria Energy Trading. ${ }^{3}$ The sector has recently drawn the attention of scholars, activists and regulators (Erklärung von Bern 2011; Interdepartmental Platform on Commodities 2013; Public Eye 2017) but even in Switzerland, its importance is still barely known outside of specialist circles.

A number of factors have combined to turn Switzerland into a commodity trading hub. The country has all the infrastructure traders need. Quick and secure access to finance and insurance, excellent virtual and physical global connections, a vibrant shipping industry, trader-friendly regulations, the proximity to international standard setters (most importantly the different UN organisations and the plethora of international lobby groups in Geneva), a highly skilled workforce, a flexible labour market and a very low corporate tax rate are just the most important factors here. Swiss neutrality and its non-membership of the UN until 2002 was another crucial element, since it allowed companies to engage in trade with countries under UN sanctions, such as apartheid South Africa or Iran.

A great many international commodity traders have their headquarters in Switzerland today. Their variety is huge - from the integrated mining and trading behemoth Glencore to large specialised trading houses like Gunvor or Cargill to trading divisions of banks and investment firms to small independent traders. About half of the roughly 400 trading firms have fewer than 10 employees, $10 \%$ have more than 300 employees. The overall number of employees in the sector is probably between $7,5^{\text {oO }}$ to 10,000 (Eggert $e t$ al. 2017; Public Eye \& Missbach 2017).

What role do these Swiss trading companies play in the global production network of Zambian copper? Export statistics offer a first approximation. According to UN Comtrade figures, around $4 \mathrm{O}^{-} 5^{\mathrm{O}} \%$ of Zambian copper has been exported to Switzerland in every year between 2006 and 2017. These statistics substantially under-report the percentage of copper traded by Swiss firms, since transit trade is difficult to classify in customs statistics. Zambian customs usually classify copper exports according to destination countries (i.e. the country to which the goods are shipped). Only when no final destination is known at the time of the sale, is the buyer's country recorded instead.

Zambian copper bought by Swiss traders is never shipped to Switzerland. Much of it is sold in transit, often from bonded warehouses. This copper will be recorded as exported to Switzerland; copper bought by Swiss companies and shipped to a known third country will be recorded as exported to this third country. When, for example, a Swiss trading company has an offtake agreement with a Zambian mining company and supplies half of this copper to a firm in China while it sells the other half from a bonded warehouse in Johannesburg, 
half of the copper bought at the mine will be recorded as exported to China, half as exported to Switzerland-even though all of it has been traded by a Swiss company. The percentage of Zambian copper traded by Swiss companies is thus probably much higher than the export figures show.

\section{Swiss trading firms in Zambia}

To understand how this trade is carried out, we use Glencore and Metal Corp Trading as two different examples. We will cover Trafigura, another big commodity trader, in the section on copper transport.

Glencore's mines market much of their copper to Glencore's trading segments, most likely through Glencore UK.4 In addition, the trading division of the company buys copper extracted by other mines in Zambia and the DRC. Since Glencore's mining and smelting operations are difficult to hide and the company has a deservedly bad reputation, it is under relatively close scrutiny by NGOs and the press.

Other Swiss traders generally remain invisible to all but industry insiders. First Quantum Minerals' trading arm Metal Corp Trading AG (Switzerland) is a case in point. First Quantum Minerals (FQM), headquartered in Canada, is the biggest copper mining company in Zambia. Its Kansanshi mine and the new Trident project produce about a third of Zambia's copper. In its Annual Information Forms, FQM claims that it has 'a limited number of off-takers' (e.g. FQM 2017: 116). This is something of an understatement. FQM sells all of its copper to just two other companies: Trafigura, long headquartered in Geneva, and Metal Corp Trading registered in Zug.

Metal Corp goes back to Republic House, a company registered in Zug in 2000 and mostly made up of traders who had worked for MRI, another Swiss trading company. Republic House was owned at least since 2005 by Energem Resources, an old player in the Southern African mining sector. (Founded as DiamondWorks, it had changed its name in 2004 after allegations of blood diamond dealings.) In preparation for a full takeover of Republic House by FQM in 2010, Energem founded Metal Corp Trading AG in Zug (Wikileaks 2005; Metal Bulletin 2010a; 2010b). Today, the company is a fully owned subsidiary of Metal Corp (Sweden) AB, itself a fully owned subsidiary of FQM.

In short, FQM's Zambian mining company sells its copper to FQM's Swiss trading company. In fact, Metal Corp Trading 'buys and sells all of FQM's metals and, in the process, carries out sophisticated derivatives management to handle price risk' (Mineman 2015). While the company has a brass plaque and a letter box in Zug, its main business is carried out through offices in London's Great Portland Street housed in the same building as First Quantum Minerals Ltd's UK headquarters.

For Metal Corp's trading arrangements, Switzerland is not important as a physical place. The copper it buys and sells does not reach the country. Its traders are not working on the shores of Lake Zug; perhaps not even the profits are stored in Swiss banks. 'Switzerland' is a regulatory regime to which 
Metal Corp rents access by paying the minimal fee of Zug's taxes. This virtual Switzerland of course intersects with the physical place. Many other trading companies have a much larger physical footprint in Switzerland, but for all of them, access to the Swiss regulatory regime is a primary asset.

\section{TRA NSPORT A N D L O G S T I C S}

\section{Transport}

Virtually all Zambian copper is exported on container ships from the harbours of Durban (South Africa), Walvis Bay (Namibia), Dar es Salaam (Tanzania) and Beira (Mozambique). On its way - usually by road - from the mines and smelters to warehouses and harbours, it has to cross at least one, often several national boundaries. Truckers and owners have to deal with difficult road conditions, frequent congestion and border delays, and sometimes theft.

Since copper is costly to transport on land, shipping costs to the harbours are a crucial factor for pricing and profits. Today, copper's world market prices are very transparent, and opportunities for arbitrage become scarcer with the omnipresence of electronic media and reporting, so that profits made on the figurative 'first and last mile' become increasingly important for traders' income (Franke et al. 2017:5). Here - in Zambian trucking, in warehousing, in crossborder paperwork -, presence on the ground, local knowledge and good connections to both local authorities and cross-border actors are indispensable (Dobler 2016), and information about transport costs is much less transparent than information about copper market prices. Consequently, some global commodity traders increasingly invest in the entire transport chain in order to become independent from logistics companies and gain control over profits in these crucial segments (Pirrong 2014: 40). Swiss companies are no exception. While Glencore has mainly invested in trucking companies transporting copper from DRC, Trafigura has moved into warehousing on the one hand, the upstream petrol logistics fuelling all transport on the other (see below).

Glencore uses the trucking company Muzuri Sana to transport copper from its Mutanda mine in DRC to warehouses in Zambia. This company, according to Zambian interview partners, is a joint venture between Mutanda and Hakuna Matata, the trucking business owned by former Katanga governor, mining mogul and opposition presidential candidate Moïse Katumbi. (In a very similar arrangement, neighbouring Tenke Fungurume Mine transports its copper to Zambia using Habari Kani trucking, also co-owned by Hakuna Matata.5)

These companies transport copper and cobalt from DRC's Katanga Province to Zambia through Kasumbalesa border post. They offload in the Zambian Copperbelt and take mining supplies back to the DRC. Subsequent transport from the Copperbelt to the harbours is handled by different companies. The main reason for this arrangement is the difficulty of transporting goods through the DRC. Legally, commodities extracted in the DRC have to be transported by companies registered in the DRC using Congolese drivers. More importantly, 
truck drivers we spoke to indicated they needed a lot of local knowledge and connections to navigate controls on DRC roads - a rather different set of qualifications than that which is needed for the routes to Gauteng or Dar es Salaam.

Swiss companies' role in transport does not stop at the harbours. Although Switzerland does not have any seaports, the world's second biggest container shipper, Mediterranean Shipping Company (MSC), is headquartered in Geneva. Along with its competitors Maersk and CMA-CGM, the company is an important player in copper shipments from Southern African harbours. All three companies offer through bill of lading services for Zambia, but since copper transport can usually be planned ahead and is highly routinised, most shippers prefer to organise their own transport, so that vessel owners like MSC only come into play at the harbour terminal. ${ }^{6}$

\section{Warehousing}

Warehousing is an integral part of logistics management. In earlier years, Zambian copper was usually stored on the mine grounds waiting to be shipped. Today, copper is mostly shipped immediately after production and stored in bonded warehouses in the Copperbelt or in neighbouring countries. Many of these warehouses are operated by international logistics companies. To these companies, warehouses are crucial for optimising truck and rail loads, for storage, repacking and blending and to regulate cash flows by storing and releasing value.

In Zambia, most international logistics companies concentrate their efforts on the route to one specific harbour. J\&J for example, a Mozambican company, concentrates on transport to Beira, while the French logistics giant Bolloré specialises in the route to Durban. The main Swiss player in the sector is Impala Terminals, Trafigura's logistics arm. Impala has heavily invested in infrastructure along the Kolwezi-Lubumbashi-Ndola-Dar es Salaam corridor. The company operates the largest single-customer terminal in Dar es Salaam harbour and uses its resources to channel copper transports to Dar (and to influence trade policies in Tanzania, including taxation and rail development). The company owns bonded warehouses in Kolwezi, Lubumbashi, Ndola and Dar, all of which have road and rail connections and can handle $20 \mathrm{ft}$ and $40 \mathrm{ft}$ containers as well as break-bulk. Along the road to Dar es Salaam, Impala has constructed dedicated truck stops as safe stopping points for copper transports (Impala Terminals 2016: 35 ).

In addition to serving Trafigura's own transports, its Ndola warehouse is an important hub for third-party copper transports from DRC and Zambia to Walvis Bay and Durban. The same is true for the second newly constructed copper warehouse, Bolloré's Chingola hub. Its main purpose is to serve as an entrepot for DRC copper and as the meeting point for the southern and northern fleets of trucks. This US\$ 10 million investment opened in May 2014 and today handles around 360,000 tons of copper, cobalt and mining reagents per year. In addition to its warehouses, trucks and terminals, Bolloré is also the biggest clearing agent in Zambia for third party shipments (Bolloré 2018). 
Most haulage, whether by road or rail, is still done by Southern African companies such as BHL, J\&J or GSM - some registered in Zambia, others in South Africa, Namibia or Mozambique. The strict contract conditions for copper transports can only be met by large transport companies, who usually own and operate a few hundred trucks. Copper cathode is transported to warehouses on either flatbed or container trucks, while transports to the harbours are exclusively done in containers to avoid reloading. (Before being loaded into containers, copper transported on flatbed trucks has to be washed, a service not all warehouses can offer (Smal 2015).) Transport contracts usually insist on convoys, GPS tracking and armed security personnel.

\section{Fuel}

Just like excavators and mine trucks, trucks and diesel trains need fuel. Supplying fuel to Zambia and the neighbouring countries is an integral part of copper logistics, and one in which a Swiss company plays an important role. Trafigura holds a $49 \%$ stake in Puma Energy, one of the most important distribution companies for petrol products in Southern Africa.

Puma has been controversial from the start, especially with respect to its Angolan investment. Twenty-eight per cent of the company, which owns most of Angola's downstream petrol business, is in the hands of Sonangol, the Angolan state oil company; another $15 \%$ is owned by Chochan Holdings, a company founded and owned by General Leopoldino ('Dino') Fragoso do Nascimento, one of the wealthiest and best-connected Angolan businesspeople-cum-politicians. In 2011 , the company bought stakes in the BP stations in Namibia (100\%), Botswana $(100 \%)$, Zambia $(75 \%)$, Malawi $(50 \%)$ and Tanzania $(50 \%)$ and took over a huge storage depot in Walvis Bay.7 In 2014, Puma Energy Africa Holdings acquired a $49 \%$ stake in the Zimbabwean company Sakunda Energy, a monopolistic fuel distribution company founded by Kudakwashe Tagwirei, a well-connected businessman with close ties to the Zimbabwean military. Through Sakunda, Puma controls the Feruka pipeline between its storage facilities in Beira and Harare, which has become a major political issue in the conflict between President Mnangagwa and the military (Africa Confidential 2018a).

Most recently, Trafigura through DTS, a $5^{\mathrm{O} / 5^{\circ}}$ joint venture between Trafigura and General Dino's Cochan, has invested towards the reopening of a crucial train route from Kolwezi in the DRC to Lobito harbour in Angola (Zambia Chamber of Mines 2018). Puma, of course, is not the only petrol company in these countries, but a good part of copper transports, whatever the shipping company, indirectly profits Trafigura.

\section{Testing, certification and surveillance}

Another very important, but often overlooked element in logistics is the certification and surveillance of goods. Traders often do not themselves have the 
possibility to assess the quality of the goods they buy and sell. Banks financing trade deals have to know their securities are worth as much as the debtor claims. Insurance companies have to make sure the insurance cover corresponds to the goods' value. Buyers want to ensure that products match their specifications before having them shipped. State agencies evaluate royalties according to metal content. In all these instances, independent inspection and verification services increase trust and enable anonymous transactions.

Perhaps not surprisingly, one of the biggest inspection companies is based in Switzerland: SGS (formerly Société Générale de Surveillance). SGS has a large footprint across the world, certifying everything from hazelnut spreads to nuclear plants, from labour rights to metal content and from fair trade to food safety. Through its involvement in industry bodies and multi-stakeholder initiatives, it is one of the most important private standard setters in the global economy (Peters et al. 2009; Bartley 2018). The company is active in many African countries. It runs Uganda's vehicle inspection, operates weighbridges, electronic cargo tracking services and import verification services for the Kenyan government and supervises road contractors in Senegal.

In Zambia, SGS owns a laboratory in the small Copperbelt town of Kalulushi that many mines rely on for ore testing; Glencore, for example, uses the lab for the samples of Katanga Mining (Katanga Mining 2018: 74, 127). Similar SGS laboratories operate in South Africa. Even more importantly, SGS supervises container packing in warehouses in South Africa and Tanzania and certifies their content. This service is crucial for trade, insurance and financing, and along with its competitors Alfred H. Knight and Alex Stewart, SGS is one of the most important players in Africa and the world. All three companies are also among the listed samplers of the London Metal Exchange.

\section{Customs}

A final Swiss input into the Zambian parts of copper's global production network needs at least to be mentioned: every good that is imported into or exported from Zambia, be it machinery, copper, sulphuric acid or oranges, is processed through a Swiss service export. Like most countries in the world, Zambia uses Asycuda (Automated System for Customs Data, currently Asycuda World) to process all customs documents. This integrated customs management software has been developed by UNCTAD in Geneva. It is one of the least known, but most important technical media of trade facilitation and standardisation. In a cloud-based service running on servers in Lusaka, transporters, clearing agents and shippers can electronically enter shipments for customs (pre-)clearance. In spite of many problems, mostly linked to server downtime, the use of Asycuda has significantly improved workflows and transparency of Zambian customs and greatly shortened processing times at the borders. It provides the state with the necessary instruments to collect revenue and gather accurate trade data, it eases financing and insurance and allows transporters and owners better control over their shipments. The 
software is thus a crucial factor in reducing transport costs and increasing efficiency, and neither transport corridors nor one-stop border posts would really work without it.

This might sound universally benign, but it also creates important and understudied distribution effects. Lower transport costs change the distribution of profits within the global production network: benefits for producing and consuming countries are generated by decreasing revenues in mining and transit countries. For resource exporting countries, they might well contribute to a further externalisation of profits, which would have to be offset by taxes or royalties in order to finance the infrastructure on which they rely.

CHALLENGES TO SWISS EXTRACTIVISM：CIVIL SOCIETY ACTORS IN Z A M B I A A D S W T Z E R L A N D

So far, we have looked at the surprising importance of Swiss corporate actors in a few segments of the global production network of Zambian copper. We have focused on corporate power and on the capacity of Swiss companies to capture value, points to which we will come back in more detail in the conclusion.

The image of Swiss extractivism would be incomplete without including the public climate in which companies operate. CSOs, NGOs, politicians (and sometimes researchers) have the potential to influence what value companies can and cannot capture, and they form a crucial part of the environment in which companies take strategic decisions. The public climate in both Zambia and Switzerland has become increasingly critical towards commodity extraction, but regulation in Switzerland is still largely favourable for international companies.

The different cantons in Switzerland compete in the national and international race for the lowest corporate tax rates. The global average for taxes on earnings, capital tax and property tax combined is 29\%; the Swiss average is $16.6 \%$, while some cantons stay below $12 \%$ (BAK Economics 2018). This is an important incentive for companies to move to Switzerland and to optimise taxes by shifting profits into the country (Cobham et al. 2014; Public Eye 2017). For international mining companies, intra-firm trade with Swiss branches can be an important avenue to lower the tax burden and increase shareholder profits. This increases the difficulties of commodity exporting countries to effectively tax extractive industries (Moore et al. 2018). Trafigura Group, for example, gives its effective global tax rate in 2017 as $8.4 \%$ (Trafigura Group Pte 2018).

It is notoriously difficult to evaluate whether all tax optimisation strategies are legal. In April 201 1, the Swiss NGO Berne Declaration (today Public Eye) jointly with other international NGOs filed a formal complaint with the OECD against Glencore and FQM for alleged breaching of OECD Guidelines (OECDWatch 2011 ). The complaint was based on a 2009 audit report conducted on behalf of the Zambian authorities (GrantThornton 2010). It alleged that FQM's 
subsidiary Mopani Copper Mines manipulated its financial accounts in order to reduce its tax bill by overestimation of operating costs, underestimation of production volumes, transfer pricing manipulation and breach of the 'arm's length' principle. The OECD's Swiss National Contact Point (NCP) handled the complaint and facilitated mediation. The result was disappointing to civil society actors. As described in the NCP's final statement in November 2012, the parties could only 'agree to disagree' - and even this agreement remains confidential.

In spite of its limited success, the example is typical for contemporary challenges to extractivism. The opposition to a company's alleged wrongdoings did not emerge from the states' regulating authorities, but from civil society actors who perceive themselves as ethics watchdogs in relation to global companies. By increasing reputational and regulatory risks, civil society actors can change business strategies and value capture (Yeung \& Coe 2015; Wright 2016). They do not remain outside of global production networks, but can become an important force shaping them.

In Switzerland, public consciousness of the economic and political weight of the commodity trade sector as well as of its problematic aspects has been growing over recent years. The Swiss public receives more information about corporate misconduct by Swiss companies in other countries than ever before. A focal point is the referendum initiative 'Responsible Business Initiative' started by an alliance of over 8o NGOs, CSOs and churches (Humanrights.ch 2017). The initiative seeks to make global compliance with environmental and human rights standards legally mandatory for all bigger companies, and to introduce the right to appeal to Swiss courts in cases of violation. It is based on the UN Guiding Principles on Business and Human Rights from 2011, which the Swiss Federal Council only implemented as voluntary recommendations. At the time of writing, both chambers of the Swiss parliament have struck down a scaled-down counterproposal, which most likely means that the Swiss people will vote on the referendum initiative in 2020.

The initiative is based on decades of solidarity and campaign work by Swiss CSOs and NGOs. Internationally, the best-known organisation campaigning for fair relations between Switzerland and poorer countries is Public Eye, but a number of smaller organisations do similar work on a grass-roots level, often in cooperation with Southern partners. Left-wing politicians have also consistently tried to change policy at a cantonal level, such as Josef Lang from the Green Alternative Party, or the Young Green Party in the Canton of Zug where Glencore and many other traders are headquartered. One strategy has been to bring poor living conditions and human rights violations around Swiss companies' plants to people's attention, an effort in which Swiss public media have played an important role. ${ }^{8}$

In Zambia, opposition to the mining industry has been present as long as commercial mining, and labour unions have strongly criticised privatisation in the 1990s (Larmer 2005, 2007). The influence of both labour unions (Uzar 2017) and civil society has been weakened by liberalisation and lack of funds, 
and by increasing state oppression under the Patriotic Front government since 2011. NGOs, often foreign-funded, such as Publish What you Pay (PWYP), ActionAid and Caritas, hold annual national and regional indabas to discuss the state of the mining sector and, to a limited extent, alternatives to mining with representatives from industry and government. Against an increasingly authoritarian state, only a small number of NGOs are in a position to speak out against the exploitation of the country's resources, mismanagement and corruption. While they work under much more difficult conditions than their Swiss counterparts, such initiatives have presented very important challenges to mining companies in Zambia.

The most successful of these initiatives is probably the legal case filed by the widower of Beatrice Mithi. Mithi, Mufulira's District Commissioner, died after inhaling sulphur dioxide released by Glencore's subsidiary Mopani Copper Mines in 2013. The year before, the Zambia Environment Management Authority (ZEMA) had found evidence of acid mists harming people and the environment in the communities of Mufulira and ordered one of Mopani's plants to be shut down because of its pollution levels. In 2016, the Kabwe High Court ruled that sulphur dioxide emissions at the copper plant caused Mithi's death, and ordered Glencore's London-listed subsidiary to pay 400,000 Zambian Kwacha in damages to the widower (Kabwe High Court 2016). Glencore had rejected the claim, citing an environmental indemnity agreement signed with the Zambian government in 200o. The judge ruled that the agreement did not apply because sulphur dioxide emissions had exceeded legal limits. Glencore has appealed the ruling at Zambia's highest court.

Another noteworthy case is not directly connected to Switzerland, but is closely watched by both civil society and companies as a possibly important precedent. Lungowe and Others versus Vedanta Resources and Konkola Copper Mines was filed extraterritorially in a UK court in 2015 . With the help of the attorneys' firm Leigh Day, 1,826 Zambians allege that as a result of toxic effluent discharge from the Nchanga Mine in Chingola (Copperbelt), they suffered loss of income since land and waterways their livelihood depended on were damaged. They further allege that many suffer personal injuries as a result of the use of polluted water. The defendants, Vedanta and its subsidiary Konkola Copper Mines, challenged the jurisdiction of the English courts. In 2016, after a three-day hearing, the Judge found an English court the most appropriate forum for the resolution of the claims and allowed the claims to proceed. The companies' appeal was dismissed by the Court of Appeal on 13 October 2017.

Despite their provisional success, both cases also show that lengthy appeals processes play in favour of companies since they can easily exhaust the plaintiffs' resources and patience (Kesselring 2016). Alliances with Northern NGOs or with legal firms who have better resources seem one way of addressing this inherent imbalance.

Not all Zambian civil society initiatives are as prominent. Many CSOs work on a local level and never reach beyond their constituencies. One recent example is 
the Mufulira NGO Forum, which demands clean drinking water from Mopani Copper Mines and campaigns both at the municipality and the mine level. Its work is partly financed by Solifonds, a Swiss NGO founded by the Swiss Federation of Trade Unions and a number of other institutions, and very active when it comes to the global role of Swiss companies (Solifonds 2018).

Other challenges to mining companies originate with the governments of commodity exporting states. A number of African governments recently introduced new mining codes (e.g. DRG) or issued large bills to companies for outstanding taxes (e.g. Tanzania and Zambia). In early 2018, the Zambia Revenue Authority (ZRA) billed FQM for outstanding import duties of US\$1 $5^{\circ}$ million and associated interest and penalties of US $\$ 8$ billion. ZRA claimed that consumables for use at the Sentinel mine (Kalumbila) were incorrectly classified as mining machinery, which do not attract import duties, from January 2013 to December 2017. FQM refutes the assessment and at the time of writing is conducting its own audit. While some argue that the tax bill is mainly an effort by the Zambian government to postpone its debt crisis by avoiding outstanding VAT repayments (Africa Confidential 2018b), the payment made international headlines and led Moody's to revise its rating outlook for FQM from stable to negative.

Such state efforts to curb corporate power today remain on a national level and often fail due to mining companies' bargaining power. While the earlier Zambian system of nationalised mines and nationalised copper marketing had many problems, it left slightly greater opportunities to lobby for higher prices and a fairer market environment. The Conseil Intergouvernemental des Pays Exportateurs de Cuivre (CIPEC), founded in Lusaka in 1967 and finally disbanded in 1988, was a state-led initiative to increase the market power of countries that depended on copper exports. While CIPEC has never really been successful (Mikdashi 1974; Kohler 1979), even the attempt to form such a group would face much higher hurdles today. The Zambian government is highly dependent on the taxes of mining companies. In all aspects of mining policy, government has to negotiate with multinational companies whose managers are under pressure to lower costs and who can pit different countries against each other. Despite state efforts to increase the development impact of mining (see Kesselring 2018a; Saunders \& Caramento 2018), the scope for government action is narrow, which leaves civil society actors in both Northern and Southern countries as the most important pressure groups.

Our examples of challenges to extractivism in Zambia and Switzerland show the importance, but also some problems and limitations of civil society action.

Firstly, all existing initiatives focus on the mining dimension of the companies, on direct consequences for affected communities and on extraordinary examples of corporate misbehaving - issues around which meaningful campaigns can be organised. Tackling everyday business practices and the consequences of less visible sides of extraction - say, trade, logistics and shipping - is much harder. Companies' inner workings remain opaque to outsiders, and the 
consequences of anonymous market forces are much more difficult to show than the consequences of, say, an acid spill.

Secondly, civil society groups as well as states struggle with firms' transnational character and their aloofness in a specific locale. Due to the complex legal structure of international companies, often no specific national jurisdiction seems to be the appropriate place to hold them to task. No transnational judicial body has the authority to investigate corporate practices across state sovereignties (Bastin 2014), and due to power imbalances between international mining corporations and governments, chances for supranational action of exporting countries seem slim.

Thirdly, in spite of public criticism, Swiss extractivism still enjoys considerable state support, both in Switzerland and Zambia. Switzerland's economy is perceived to greatly benefit from transit trade (Beusch et al. 2013). Zambia in turn has little choice but to rely on international investors for tax income and for employment, leaving the government with few resources against corporate bargaining power.

CONCLUSION: VALUE CAPTURE IN GLOBAL EXTRACTIVISM

We have traced different ways in which Swiss companies are active in global production networks of copper mined in Zambia. Our focus has been very restricted. We have only analysed the relatively small segment between mining and Southern African harbours. We have not considered what happens upstream from mining - say, in mining machinery, supplies, patents or engineering education; nor have we analysed subsequent processing after copper leaves the continent. We have completely ignored finance and insurance, in which Swiss companies play a crucial role globally, and have left aside the role of Swiss capital invested elsewhere.

Despite such limitations, a clear image has started to emerge. We have learnt about Switzerland's role in Zambia's copper sector and we can learn from it.

What did we learn about Switzerland's role? First of all: it is more important than most people, us included, would have assumed. While only one of the five major mining companies in Zambia is headquartered in Switzerland, a substantial part of copper trade, logistics, certification and to some degree transport is conducted by Swiss companies. It is very difficult to quantify Swiss involvement; exact figures are hard to come by and the 'Swissness' of multinational firms is often impossible to measure. Yet for a country of just over 8 million inhabitants, Switzerland certainly plays an outsized role. While the country's transit trade has been attracting more scrutiny over the last years, other aspects of Swiss involvement have largely remained unnoticed.

If our data can be generalised, Swiss companies involved in commodity extraction typically invest in services rather than in extraction itself. Services, unlike extraction, require a comparatively low or mobile investment and provide stable profits relatively independent from prices. Techniques and know-how, which of course are very important for these services, are usually much more 
adaptable to different commodities than is the case for extraction. In short, services are more mobile and less dependent on one single country or one single commodity market than mining.

This tendency towards flexibility explains the avenues in which Swiss services companies usually expand into developing markets. They acquire successful local companies and integrate them into a global brand. Through such acquisitions, they can appropriate local expertise and credibility and combine it with their own global reach and international reputation. This, as well, allows companies to balance different markets against each other, keeping losses local and appropriating gains (see also Parker et al. 2018: $5^{6}$ ).

In short: the Swiss service economy can profit from global extraction largely without suffering from the downsides of extractivist dynamics. Swiss firms typically build and maintain the infrastructure of global commodity trade instead of committing to the big localised investment needed in mining. In doing so, they continue a long history of Swiss facilitation of global trade, from the slave trade to apartheid gold.

Not all Swiss companies are the same. Some have originated in Switzerland, while others have only recently moved there. Different global companies are attracted by different aspects of the Swiss model as we have described it; some look for a favourable tax regime and do not need much more than a letterbox in Zug, while others seek access to the trade and finance hub and the qualified personnel working in it. Some Swiss companies - Glencore or Trafigura - are themselves vertically integrated, extending their limbs into many countries, while others - Metal Corp - are merely one local part of a global company.

Whatever their role and scope, they can no longer rely on remaining unchallenged. The stark difference in living conditions between Switzerland and many countries in which Swiss companies are active draws criticism and, increasingly, calls for regulation and control. The greatest asset of Swiss-based companies, their ability to bridge markets and extract value from all of them, can then become a liability. The global connectedness of Swiss companies might also create conditions under which civil society pressure in Switzerland can create material changes for people living in other countries.

What do these insights into Swiss-Zambian economic relations teach us about the economic structures of extractivism?

First of all, it would be a mistake for all people involved - scholars, activists, regulators - to concentrate on mines and wells alone when trying to understand extractivism. The sites of extraction are massive, prominent and visible. They have a huge ecological, economic and social impact. This prominence tends to hide the infrastructure that enables them to work. The service sector is an important part of this infrastructure, and one in which a sizeable part of the profits from extraction can be earned.

Servicification affects the distribution of profits as much as the globalisation of mining does. Economists have argued that asymmetric power structures in global value chains lead to an uneven distribution of profits (e.g. Milberg 2004; Heintz 2006), and that domestic added value can decline with the 
integration into global value chains 'due to an injection of foreign high-skilled labor content in their exports' (Carballo \& Jiang 2016) - a process as clearly visible in the share of expatriate workers in the higher pay-grades of Zambian mines as in the reliance of logistics companies on know-how produced in higher-paying countries. When it comes to mineral extraction in Africa, analyses of these tendencies have rarely taken the service sector into account. We do not have sufficient quantitative data to clearly substantiate this, but our qualitative analysis shows that higher-skilled service tasks that create stable added value are increasingly taken over by international companies.

These trends change the distribution of profits in global production networks. In such networks, a large number of actors in different countries jointly create value which, when it meets demand on the market, can translate into profits. The production network does not only organise the cooperation between the actors; it also is a mechanism to assign a relative value to each of the actors' contributions, and to remunerate them accordingly. The different actors have different capacities to convince others of the value of their activities, and consequently to capture value within the network.

Dependence on commodity extraction is problematic for poorer countries for two main reasons. Firstly, it leaves them with only those segments of the production network in which relatively little value is (defined as being) produced. Secondly, a comparatively large percentage of the profit generated even in these sectors is exported to other national economies as dividend on capital investment, so that it cannot be invested to develop economic alternatives to extraction in mining countries.

As our discussion of Switzerland's role in Zambia shows, both arguments hold true for the infrastructure of extraction. Between the mines and the harbours, a great many actors add value to copper - from states building roads and railways to logistics companies to truck drivers, filling-station attendants, security guards or roadside food sellers. Each of them creates value, but their ability to capture parts of the overall value creation widely differs. Swiss companies are among those who have been most successful in getting a share of the value added to copper between its extraction and its use in industrial production. Their competitive advantages allow them to flexibly invest in the most lucrative segments of copper's production networks. As a consequence, they are able to generate and appropriate an increasing part of the profits generated in the Southern African segments of copper's value chain - profits that then improve lives on the shores of Lake Zug, not in Zambia.

The preconditions for Switzerland's favourable place in global commodity chains are know-how, access to finance, global reputation and not least political stability. These have also turned the country into a centre of international organisations and global regulation - a proximity that again creates an advantage for companies based there. All these advantages allow Swiss companies to control essential parts of copper's global production network, and to generate a great amount of profits on the way. 
The unequal distribution of profits should also make governments think twice about the usefulness of infrastructure projects that link the sites of extraction to global markets (Nugent 2018). They might increase economic activity, but without additional changes, the odds are that global companies will earn the windfalls while national taxpayers will face the debts (Kesselring 2017, 2018b).

Mining has often been presented as a dirty business linked to environmental degradation, human rights violations, corruption and tax evasion. Civil society and at least in part governmental actors have focused on such problems. The case study we discussed shows that, while such a focus on corrupt practices is important, civil society should also discuss the normalised uneven allocation of profits, wages, taxes and benefits. In the financialised global economy, capital owners' shares in profits have been increasing for decades. Since the capital invested in extractive industries and related services generally comes from rich Northern countries, this has also shifted the balance of profits between the global North and the global South. Attempts to redress this shift and to increase the share of profits remaining in a commodity exporting country can use each of the classic factors of production as a lever: land by increasing mining royalties, labour by negotiating better wages, higher-paying jobs or higher rates of employment, and capital by increasing either taxes or ownership. Zambia has tried, and failed, on all these fronts, and in spite of the commercial success of its mining sector, the country is confronted with increasing economic insecurity.

For Switzerland, Zambia's mining industry has had the opposite effect. Swiss companies have found lucrative, low-risk investment opportunities in Zambia by targeting mineral logistics and trade. Mining in Zambia thus creates a steady stream of income for companies registered in Switzerland, while much of the economic, political and environmental costs of mining are borne by Zambians.

\section{NOT E S}

1. Some of the information in this article comes from, or was corroborated by, interviews with senior management at Kansanshi mine owned by First Quantum Minerals (FQM). For a period in 2016, we had access to a number of senior employees and managers. The interviews were taped with the interviewees' consent. When we approached the mine's general manager for an interview, however, he denied the request. He made clear that interviewees, in his view, had violated internal procedures by speaking to us without authorisation by FQM's board. As a consequence, we have decided to use the material obtained through freely given interviews, without however giving the names of interviewees or assigning quotes. Much of the information given in the interviews was corroborated by other sources.

2. Mistakidis resigned as Glencore's head of global copper trading by the end of 2018 amid inquiries of Ontario's Security Commission and the US Department of Justice about Glencore's Katanga mines. See e.g. Bloomberg (2018) and Canadian Lawyer (2019).

3. Handelszeitung (2018). Most of these companies have different seats; Cargill mainly operates from Minnesota, USA, while Trafigura has its headquarters in Singapore. The figures reflect the official Swiss economic statistics about companies based in the country.

4. 'Glencore has a $100 \%$ off-take agreement with Mopani for the life of the mines, with ownership transferred to Glencore at the mine gate and pricing based on LME prices', according to Glencore's 2011 IPO prospectus (Glencore 2011: 85). See also footnote 23 in the OECD complaint Sherpa et al vs Glencore International AG (OECDWatch 2011). 
5. According to the LinkedIn profile of its traffic manager. We were unable to independently verify the company's ownership.

6. Through bill of lading service has two main advantages for Zambian customers: It guarantees access to empty containers for loading (since Zambia does not have an empty container depot, containers used by independent shippers have to be pre-ordered from South Africa, often at several weeks' notice); and it shifts the risk of demurrage (fines paid for late arrival of goods loaded on vessels) to the transporters hired by the carrier. None of these advantages is usually worth its cost for high volume copper transport through warehouses. - On MSC's role in shipbreaking, one of the endpoints of copper's value chain, see Daems \& Goris (2019).

7. Sonangol and the entourage of José Eduardo dos Santos are linked to Switzerland in different ways, allegedly using its banks as conduits for money gained in corrupt deals. In spite of several charges, no Swiss court has so far found anyone guilty in this regard; e.g. OSISA (2014).

8. An important example is Res Gehriger's television contributions, which helped to expose excessive pollution by Glencore's smelter in Mufulira - see SRF (2014, 2016).

\section{R E F E R E N C E S}

Africa Confidential. 2018a. 'Trafigura in a tug-of-war', 59, 22 (9 November): 1-3.

Africa Confidential. 2018b. 'As the debts balloon, Lungu avoids the spotlight', 59, 8 (20 April): 1-3.

Acosta, A. 2013. 'Extractivism and neoextractivism: two sides of the same curse', in M. Lang \& D. Mokrani, eds. Beyond Development: alternative visions from Latin America. Quito: Fundación Rosa Luxemburg: 61-86.

Adam, Ch. \& A. Simpasa. 2010. 'The economics of the copper price boom in Zambia', in A. Fraser \& M. Larmer, eds. Zambia, Mining, and Neoliberalism: boom and bust on the globalized Copperbelt. New York, NY: Palgrave Macmillan, 59-9o.

Ayelazuno, J.A. 2014. 'The "new extractivism" in Ghana: a critical review of its development prospects', The Extractive Industries and Society 1, 2: 292-302.

BAK Economics. 2018. <http://www.baktaxation.com/en/pages/bak-taxation-index/uebersicht.php>, accessed 7.2.2019.

Bartley, T. 2018. Rules Without Rights: land, labor, and private authority in the global economy. Oxford: Oxford University Press.

Bastin, L. 2014. 'Transfer pricing and the WTO', Journal of World Trade 48, 1: 59-80.

Benya, A. 2015. 'The invisible hands: women in Marikana', Review of African Political Economy 42, 146 : $545^{-60 .}$

Beusch, E., B. Döbeli, A.M. Fischer \& P. Yesin. 2013. Merchanting and Current Account Balances. Basel: Swiss National Bank.

Bloomberg. 2017. <https://www.bloomberg.com/news/articles/201 7-05-2 1/commodity-traders-lamentworld-where-everybody-knows-everything >, accessed 7.2.2019.

Bloomberg. 201 8. <https://www.bloomberg.com/news/articles/2018-10-og/is-the-reign-of-glencore-s-billionaire-copper-king-near-its-end $>$, accessed 7.2.2019.

Bolloré. 2018. <https://www.bollore-logistics.com/en/Pages/FOCUS/Zambia.aspx>, accessed 7.2.2019.

Canadian Lawyer. 2019. <https://www.canadianlawyermag.com/author/anita-balakrishnan/lawyersseeing-steep-penalties-in-securities-settlements-16670>, accessed 7.2.2019.

Caraballo, J. \& X. Jiang. 2016. 'Value-added erosion in global value chains: an empirical assessment', Journal of Economic Issues 50, 1: 288-96.

Cobham, A., P. Janský \& A. Prats. 2014. Estimating Illicit Flows of Capital via Trade Mispricing: a forensic analysis of data on Switzerland. Washington, DC: Center for Global Development.

Craig, J. 2001. 'Putting privatisation into practice: the case of Zambia Consolidated Copper Mines Limited', Journal of Modern African Studies 39, 3: 389-410.

Daems, E. \& G. Goris. 2019. Behind the Hypocrisy of Better Beaches: shipbreaking in India, ship owners in Switzerland, lobbying in Belgium. Brussels: Shipbreaking Platform.

Dobler, G. 2016. 'The green, the grey and the blue: a typology of cross-border trade in Africa', Journal of Modern African Studies 54, 1: 145-69.

Dobler, G. 2017. 'China and Namibia, 1990 to 2015: how a new actor changes the dynamics of political economy', Review of African Political Economy 44, 153: 449-65.

Dolan, C \& D. Rajak, eds. 2016. The Anthropology of Corporate Social Responsibility. New York, NY: Berghahn Books.

Eggert, N., G. Ferro-Luzzi \& D. Ouyang. 201 7. Commodity trading monitoring report. Geneva: SRIC and IREG. $<$ https://archive-ouverte.unige.ch/unige:94096>. 
Engels, B. \& K. Dietz, eds. 2017. Contested Extractivism, Society and the State-Struggles over Mining and Land. London: Palgrave Macmillan.

Erklärung von Bern, ed. 201 1. Rohstoff: Das gefährliche Geschäft der Schweiz. Zürich: Salis Verlag.

Fässler, H. 2005. Reise in Schwarz-Weiss. Schweizer Ortstermine zur Sklaverei. Zürich: Rotpunktverlag.

FQM 2002. <http://www.infomine.com/index/pr/Paog4754.PDF>, accessed 7.2.2019.

FQM 2017. First Quantum Minerals Ltd. Annual Information Form. As at December 31, 2016. <https://sedar. com/DisplayCompanyDocuments.do?lang=EN\&issuerNo=0ooo6237>, accessed 7.2.2019.

Franke, A., R. Rechsteiner \& G. Sharp. 201 7. The Endgame for Commodity Traders. Zürich: Oliver Wyman.

Fraser, A. \& M. Larmer. 2010. 'Introduction: boom and bust on the Zambian Copperbelt', in A. Fraser \& M. Larmer, eds. Zambia, Mining, and Neoliberalism: boom and bust on the globalized Copperbelt. New York, NY: Palgrave Macmillan, 1-30.

Gereffi, G. 2014. 'Global value chains in a post-Washington consensus world', Review of International Political Economy 21, 1: 9-37.

Glencore. 201 1. <https://www.glencore.com/dam/jcr:268b58d2-61 b8-44d 1-997a-1 7e76bb66f93/FinalProspectus-3-May-201 1-lowres.pdf $>$, accessed 7.2.2019.

Glencore. 2018. Annual Report 2OI 7. Baar: Glencore plc.

GrantThornton. 2010. Pilot Audit Report: Mopani Copper Mines Plc. <http://www.facing-finance.org/wpcontent/blogs.dir/16/files/2012/o3/2010_Report_audit_Mopani.pdf>, accessed 7.2.2019.

Gudynas, E. 2018. 'Extractivism', in R. Munck \& R. Delgado Wise, eds. Reframing Latin American Development. New York, NY: Routledge: 61-77.

Haller, L. 2019. Transithandel: Geld- und Warenströme im globalen Kapitalismus. Frankfurt: Suhrkamp.

Handelszeitung. 2018. <https://www.handelszeitung.ch/unternehmen/glencore-ist-das-grosste-unternehmen-der-schweiz>, accessed 7.2.2019.

Heintz, J. 2006. 'Low-wage manufacturing and global commodity chains: a model in the unequal exchange tradition', Cambridge Journal of Economics 30: 507-20.

Humanrights.ch. 2017. <https://www.humanrights.ch/en/switzerland/foreign-affairs/foreign-trade/ kovi/responsible-business-initiative>, accessed 7.2.2019.

Impala Terminals. 2016. Impala Terminals Corporate Brochure. Geneva: Impala Terminals.

Interdepartmental Platform on Commodities. 2013. Report of the Interdepartmental Platform on Commodities to the Federal Council-Background Report: Commodities. Bern: EDA.

Kabwe High Court. 2016. Judgment Mithi vs Mopani. <https://www.srf.ch/news/content/download/ $11003760 /$ file/Urteil\% 2oHigh\% 20 Court $\% 20 \% 20 \% 28002 \% 29 . p d f>$, accessed 7.2.2019.

Katanga Mining Ltd. 2018. NI43-101 Technical Report on the Material Assets of Katanga Mining Limited. <http://www.katangamining.com/ /media/Files/K/Katanga-mining-v2/operations/reportsoperation al/technical-report-march-2018.pdf $>$, accessed 7.2.2019.

Kesselring, R. 2016. Bodies of Truth: law, memory and emancipation in South Africa. Stanford, CA: Stanford University Press.

Kesselring, R. 2017. 'The electricity crisis in Zambia: blackouts and social stratification in new mining towns', Energy Research E' Social Science 30: 94-102.

Kesselring, R. 2018a. 'The local state in a new mining area in Zambia's Northwestern Province', in J. Schubert, U. Engel \& E. Macamo, eds. Extractive Industries and Changing State Dynamics in Africa: beyond the resource curse. New York, NY: Routledge, 129-47.

Kesselring, R. 2018b. 'At an extractive pace: conflicting temporalities in a resettlement process in Solwezi, Zambia'. The Extractive Industries and Society 5, 2: 237-44.

Kirsch, S. 2014. Mining Capitalism: the relationship between corporations and their critics. Berkeley: University of California Press.

Kohler, W. 1979. Multinationale Konzerne und die Chance von Entwicklungsländern auf eine eigenständige Rohstoffpolitik: das Beispiel der CIPEC. Konstanz: Universität Konstanz.

Lannen, A., E. Bürgi Bonanomi, S. Rist \& J. Wehrli. 2016. Switzerland and the Commodities Trade: taking stock and looking ahead. Swiss Academies Factsheets 11 (1). Geneva: Swiss Academies of Arts and Sciences.

Larmer, M. 2005. 'Reaction and resistance to neo-liberalism in Zambia', Review of African Political Economy 32, 103: 29-45.

Larmer, M. 2007. Mineworkers in Zambia: labour and political change in post-colonial Africa. London: Tauris Academic Studies.

Lee, C.K. 2017. The Spectre of Global China: politics, labor, and foreign investment in Africa. Chicago, IL: University of Chicago Press.

Manley, D. 201 7. Ninth Time Lucky: is Zambia's mining tax the best approach to an uncertain future? New York, NY: Natural Resource Governance Institute. 
Metal Bulletin. 2010a. <https://www.metalbulletin.com/Article/2397816/Republic-House-sets-up-MetalCorp-Trading-ahead-of-First-Quantum-takeover.html>, accessed 7.2.2019.

Metal Bulletin. 2010b. <https://www.metalbulletin.com/Article/2386951/First-Quantum-seeks-to-buyRepublic-House.html>, accessed 7.2.2019.

Milberg, W. 2004. The Changing Structure of International Trade Linked to Global Production Systems: what are the policy implications? Geneva: International Labour Organization Policy Integration Department.

Mineman. 2015. <http://www.mineman.com/News/2013-(2)/Training-in-London-for-Metalcorp-Trading. aspx $>$, accessed 7.2.2019.

Mikdashi, Z. 1974. 'Collusion could work', Foreign Policy 14: 57-68.

Miroudot, S. 2017. The Servicification of Global Value Chains: evidence and policy implications. Geneva: UNCTAD.

Moore, M., W. Prichard \& O.-D. Fjeldstad. 2018. Taxing Africa: coercion, reform and development. London: Zed Books.

Nugent, P. 2018. 'Africa's re-enchantment with big infrastructure: white elephants dancing in virtuous circles?', in J. Schubert, U. Engel \& E. Macamo, eds. Extractive Industries and Changing State Dynamics in Africa: beyond the resource curse. New York, NY: Routledge, 22-40.

OECDWatch 2011. <https://www.oecdwatch.org/cases/Case_208/925/at_download/file>, accessed 7.2.2019.

OSISA. 2014. <http://jss.osisa.org/law/angola/no-investigation-corrupt-russia-angola-debt-deal.html $>$, accessed 7.2.2019.

Parker, R., S. Cox \& P. Thompson. 2018. 'Financialization and value-based control: lessons from the Australian mining supply chain', Economic Geography 94, 1: 49-67.

Peters, A., L. Koechlin, T. Förster \& G. Fenner Zinkernagel, eds. 20og. Non-State Actors as Standard Setters. Cambridge: Cambridge University Press.

Pirrong, C. 2014. The Economics of Commodity Trading Firms. Geneva: Trafigura.

Public Eye. 2017. The 'Paradise Papers', Switzerland and Commodities. Bern.

Public Eye \& A. Missbach. 2017. Alternative Facts from the Swiss Commodity Trading Lobby. Bern: Public Eye.

Saunders, R. \& A. Caramento. 2018. 'An extractive developmental state in Southern Africa? The cases of Zambia and Zimbabwe', Third World Quarterly 39, 6: 1166-9o.

Schubert, J., U. Engel \& E. Macamo, eds. 2018. Extractive Industries and Changing State Dynamics in Africa: beyond the resource curse. New York, NY: Routledge.

Simutanyi, N. 1996. 'The politics of structural adjustment in Zambia'. Third World Quarterly 17, 4: 825-39.

Smal, D. 2015. Zambia's Dependability: imports and exports. (Young international freight forwarder of the year award). Lusaka: Privately printed.

Solifonds. 2018. 'AnwohnerInnen in Mufulira fordern sauberes Wasser jetzt!', Solifonds Informationsbulletin 106: $1-3$.

SRF. 2014. <https://www.srf.ch/news/schweiz/glencore-xstrata-und-die-asthma-toten-von-mufulira >, accessed 7.2.2019.

SRF. 2016. <https://www.srf.ch/news/wirtschaft/gericht-in-sambia-verurteilt-glencore-kupferwerk >, accessed 7.2.2019.

Trafigura Group Pte. 2018. 2017 Annual Report: advancing trade. Singapore: Trafigura.

Uzar, E. 2017 . 'Contested labour and political leadership: three mineworkers' Unions after the opposition victory in Zambia'. Review of African Political Economy 44, 152: 292-311.

Welker, M. 2014. Enacting the Corporation: an American mining firm in post-authoritarian Indonesia. Berkeley, CA: University of California Press.

Wikileaks. 2005. <https://wikileaks.org/plusd/cables/o5PRETORIAı o99_a.html>, accessed 7.2.2019.

Womin, African Women Unite Against Destructive Resource Extraction. 2013. Women, Gender and Extractivism: a collection of papers. Johannesburg. <https://www.womin.org.za/images/papers/Full-collection-Women-gender-and-extractivism-in-Africa.pdf.

Wright, C. 2016. 'Leveraging reputational risk. Sustainable sourcing campaigns for improving labour standards in production networks', Journal of Business Ethics 137, 1: 195-210.

Yeung, H.W. \& N. Coe. 2015 . 'Toward a dynamic theory of global production networks', Economic Geography 91, $1: 29-58$.

Zambia Chamber of Mines. 2018. <http://mines.org.zm/trafigura-group-helps-re-establish-historicafrican-trade-route>, accessed 7.2.2019.

Zambia EITI. 2017. Extractive Industries Transparency Initiative (EITI). Eighth Report for the Fiscal Year ended $3 I$ December 2015 . Lusaka: EITI. 